\title{
Health Care Waste Management Practice amongst Health Care Workers in Health Facilities in Bida Local Government Area, Niger State - Nigeria
}

\author{
Article by Otojareri K.A ${ }^{1}$, Omosigho O P ${ }^{2}$, Otojareri U.C.G ${ }^{3}$, Emumwen E.G ${ }^{2}$ \\ ${ }^{1}$ NHIS Unit, Federal Medical Centre Bida. Niger State Nigeria \\ ${ }^{2}$ Medical Microbiology Dept., Federal Medical Centre Bida. Niger State Nigeria \\ ${ }^{3}$ Nursing Division, Umaru Sanda General Hospital Bida, Nigeria \\ Email: otojareri.kohwo@yahoo.com ${ }^{1}$
}

\begin{abstract}
Health care wastes $(\mathrm{HCW})$ are all waste generated from health care facilities, research facilities and other associated laboratories. The aim of this study is to determine the knowledge, attitude, practice and factors affecting health care waste management practice amongst health care staff in health facilities in Bida Local Government Area. This descriptive study was carried out among health care personnel in all the health facilities in Bida Local Government. The respondents who had worked in the health facilities for a period of one year and above were studied. The tools for data collection were semi structured questionnaires and observational checklist. A total of 314 respondents were interviewed. The mean age of respondents was 33.8 \pm 6.8 years. The level of knowledge of health care staff in the health facilities was fair. Respondents' attitudes were excellent in $22.3 \%$, good in $46.8 \%$ and poor in $30.9 \%$. Respondents' practice of health care waste management (HCWM) was fair in $56.4 \%$, excellent in $23.6 \%$ and poor in $20.1 \%$. Also, noted was that awareness of existing policy on HCW, a standing Supervisory Committee on $H C W$ in the various health facilities affected positively the practice of HCWM. The study showed that the level of knowledge and attitude amongst health staff in health care facilities in Bida Local Government was fair and their current practice of health care waste management was found to be good. From the findings in the study, the knowledge, attitude and practice of health care waste management amongst health care staff can be improved by organizing training and retraining programmes like workshops, seminars etc. Policies on health care waste management should be widely circulated to improve the awareness amongst health care staff.
\end{abstract}

Keywords: Health Care Waste; Health Care Waste Management, Bida Local Government Area.

\section{Introduction}

Waste according to Basel convention is any substance or objects which are supposed to be disposed or which are required to be disposed by the provision of law ${ }^{1}$. Waste can also be defined as product arising from humans activities that are discarded because there are no longer useful and could be solid, liquid or gases. $^{1}$

Health care waste can be defined as any waste, which is generated during the diagnosis treatment or immunization of human beings or animals or in the production or testing of biologicals, irrespective of the volume, characteristics and composition. ${ }^{2}$ Health care waste $(\mathrm{HCW})$ has also be defined as all wastes generated from health care and health research facilities and associated laboratories. ${ }^{3}$

The World Health Organization (WHO) defines health care waste (HCW) as the total waste stream from a health care or research facility that includes both potential risk waste and non-risk waste materials. ${ }^{4}$ Health care wastes can also be categorized in the following way viz - infectious wastes which includes wastes suspected to contain pathogens e.g. laboratory cultures, waste from isolation wards, tissues (swabs), materials or equipment that have been in contact with infected patients, excreta, pathological waste includes human tissues or fluids e.g. body parts, blood and other body fluids, fetuses. Sharps which consists of sharps waste and it includes needles, infusion sets, scalpels, knives, blades, 
broken glasses. Pharmaceutical waste which are wastes containing pharmaceuticals such as pharmaceuticals that are expired or no longer needed, items contaminated by germs or containing pharmaceuticals (boxes, bottles). Waste with high content of heavy metals which could be a sub classification of chemicals waste which are usually highly toxic such as batteries, broken thermometers, blood pressure gauge etc. Pressurized containers which are potentially harmful gas in containers such as gas cylinders, gas cartridges and aerosol cans. Radioactive waste which are wastes from ionizing radiotherapy or laboratory research, contaminated glassware, packages such as alpha particles, beta particles, and gamma rays. About $75 \%$ to $90 \%$ of wastes produced by health care providers is "non risk or general" health care waste whilst the remaining $10 \%$ to $25 \%$ of health care waste is regarded as hazardous and may create a variety of health risk. ${ }^{2,4}$

Health care waste management is therefore defined as a discipline associated with control of health care waste generation, collection, storage, transfer and transport, processing and disposal of solid wastes in a manner that is in accordance with the best principle of public health, economics, engineering, conservation and other environmental conditions. ${ }^{1}$

Effective management or disposal of hospital waste should include basically, storage in generating premises, effective collection, effective transportation and proper disposal. However, in Nigeria a report by Coker et al states that there is a near total absence of institutional arrangement for the management of medical wastes. ${ }^{5}$ there are steps in management of health care wastes. Segregation of hospital wastes in which there is separation of different types of wastes at the point of generation and keeping them isolated from each other. Segregation is the most important step in the entire process of hospital waste management. There is need for special attention to be given to the relatively small quantities of infectious and hazardous waste thereby reducing not only the risk but also the cost of handling, treatment and disposal. The most appropriate way of identifying the categories of waste is by sorting the waste into colour coded plastic bags or containers. ${ }^{6}$

With the increase in health care waste generation from health care facilities coupled with lack of trained work force to manage health care waste, the individual, community, would continue to suffer hazards from exposure to health care waste.

This study which is to determine the level of knowledge, attitude, practice and factors affecting practices of health care waste management amongst health care staff of health facilities in Bida Local Government Area, will help provide information and create awareness on the health care staff and the public of hazards that can arise from health care waste and its effects. This will help to improve the attitude of health care personnel and the management of the hospitals to health care waste management. The current practices on HCWM are expected to improve in our health facilities. To the Government/Ministry of Health the study would help remind those in leadership positions of the need to ensure that policies on health care waste management are implemented.

\section{Materials and method}

A descriptive cross sectional study was carried out amongst three hundred and fourteen (314) health care workers handling health care waste in the health facilities which includes a Federal Medical Centre (F.M.C), a general hospital, five primary health care clinics and 2 dispensaries in Bida local government area. Only those health care workers who had spent a year and above in service were included in the study the study was carried out between February and April 2011

\section{Study population}

Bida, the second largest town in Niger state. It is a local government area in Niger state Nigeria. The local government area covers an area of 51 square kilometers and has a population of $188,181 .^{7}$ Bida is located South-West of Minna the capital of Niger state, about $9 \mathrm{~km}$ North of River Kaduna, along BidaMokwa road. It is a dry and arid town and the major ethnic group is Nupe. Bida is the head quarter of the Nupe kingdom and the title by which their king is called is 'Etsu Nupe'. The town is known for its production of tradition crafts notably glass and brass ware. Bida is also known for its Durbar festival.Bida 
local government is made up of fourteen wards. Federal government institutions sited in the town are; The Federal Polytechnic, National Cereals Research Institute. There are about 9 government health institutions which includes, a Federal Medical Centre (F.M.C), a general hospital, five primary health care clinics and 2 dispensaries. There are also 5 private health institutions. There are other social amenities in the town like pipe borne water and electricity supply.

\section{Sampling method}

A total population study was carried out amongst three hundred and fourteen (314) health care workers. Using the exclusion criteria health care workers in the various health facilities that were less than a year in service were excluded from the study.

Two tools, questionnaire and observation check list were used to collect data for the study. The semi structured questionnaires consisted of open and closed ended questions was administered by interviewers. Qualitative information were sought on sociodemographic characteristics of respondents, their knowledge, attitude, practice of health care waste management and factors affecting the practice of health care waste management.

Observational checklist was used to check for the presence of certain equipments in the premises of all fourteen (14) health care facilities in Bida Local Government where the health care workers worked. Items that were checked for were colour coded bins, protective gadgets used by the hospital assistants handling health care waste, incinerator, and disposal sites within the health facilities.

\section{Data management}

A day was set aside for the training of two research assistants, an infectious control staff and a medical laboratory scientist. They were trained on the appointed day and during the period of the pretest, on how to interview participants for the study.

Pretest: To ensure appropriate data collection, questionnaires were pretested at Kutigi rural hospital, Kutigi which was about $48 \mathrm{~km}$ from Bida. From the pretest, necessary corrections in the questionnaires were made before the commencement of the study.

Statistical Package for Scientific Solution (SPSS) Version 16 was used for coding and analysis of data. Data were presented in words, frequency distribution tables and charts. Chi-square statistical test of association and test of significance were carried out where applicable and the level of significance set at $\mathrm{p}<0.5$ and confidence level at $95 \%$.

\section{Ethical consideration}

Ethical approval for this study was giving by Health department of Bida local government Verbal consent were obtained from the participants after full explanation for the reason of the study including its risk and benefits. Consent was also obtained from the management of the various health facilities used in the study following an explanation of the benefits of the study.

\section{Results}

The mean age of the respondents was 33.8 6.8 years. A higher proportion of respondents $156(49.7 \%)$ were in the age group 31-40 years, followed by 111 (35.4\%) in 21-30years age group and only nine (9\%) were in age group 51-60 years. Half of the respondents $158(50.3 \%)$ were females while $156(49.7 \%)$ were males. A higher proporiton of the respondents $62.7 \%$ were married and $36.3 \%$ were single. A higher proportion of the respondents $148(47.1 \%)$ were nurses, followed by doctors $16.9 \%$ and others comprising physiotherapist, radiographers etc. 6.1\%. Over half of the respondents $174(55.5 \%)$ had worked for 1 5years, followed by respondents $70(22.3 \%)$ who had worked for 6-10years and $24(8.7 \%)$ had worked over 20 years. (Table 1)

Table 2 shows that over half of the respondents 166 ( 52.9\%) worked with the tertiary health care institutions, followed by $82(26.1 \%)$ respondents who worked with the secondary health institutions, 40 
Texila International Journal of Public Health

Volume 5, Issue 3, Sep 2017

(12.7\%) worked with the primary health care centre (P.H.C.C) and only three respondents, $3(1.0 \%)$ worked with the dispensaries.

A higher proportion of respondents $213(67.8 \%)$ had knowledge of General waste, followed by 151 $(48.1 \%)$ that knew of infectious waste whilst $58(18.5 \%)$ knew of waste with high content of heavy metals.0020 (Table 3)

Over half of respondents 177 (56.4\%) mentioned incineration as method of health care wastes disposal, followed by $75(23.9 \%), 40(12.7 \%)$ that mentioned open burning and open dumping respectively as methods of disposal whilst only $22(7.0 \%)$ mentioned disposal method is by local council authority.(Table 4)

Table 5 shows a higher proportion of respondents $63.2 \%$ that were aware of a policy on health care waste management knew of incineration as a method of waste disposal. There was a statistically significant association between awareness of policy and knowledge of method of waste disposal. $(\mathrm{p}=0.011)$

A higher proportion of respondents that had knowledge of waste segregation $24.8 \%$ and $57.0 \%$ had excellent and fair practices respectively. There was a statistically significant association between knowledge of waste segregation and practice. (Table 6)

A higher proportion of respondents 289 (92.0\%) felt health care waste management was everyone's responsibility, $268(85.4 \%)$ felt it was an issue, $117(37.3 \%)$ respondents saw it as an extra burden on clinical staffs, 116(36.9\%) felt it was the responsibility of only clinical staffs, whilst only 97 (30.9\%) felt it was government responsibility. (Table 7)

A higher proportion of respondents $28.8 \%$ that were aware of a policy on health care waste management had excellent practice of HCWM while 58.6\% though not aware of the policy had fair practice. There was a statistically significant association between awareness of health care waste policy and its practice. $(\mathrm{p}=0.005)$ (Table 8)

Table 1. Socio-demographic data

\begin{tabular}{lll}
\hline Variable & Frequency $(\mathbf{N}=\mathbf{3 1 4})$ & Percent \\
\hline Age (years) & & \\
$21-30$ & 111 & 35.4 \\
$31-40$ & 156 & 49.7 \\
$41-50$ & 38 & 12.1 \\
$51-60$ & 9 & 2.8 \\
Sex & 156 & 49.7 \\
Male & 158 & 50.3 \\
Female & 114 & 36.3 \\
Marital status & 197 & 62.7 \\
Single & 3 & 1.0 \\
Married & 53 & 16.9 \\
Widowed & 148 & 47.1 \\
Occupation & 23 & 7.3 \\
Doctor & 22 & 7.0 \\
Nurse & 26 & 8.3 \\
Medical laboratory scientist & 23 & 7.3 \\
Pharmacist & 19 & 6.1 \\
Hospital assistant & 174 & 55.5 \\
Community health officer & 70 & 22.3 \\
Others & 36 & 11.4 \\
Work experience (years) & 10 & 3.2 \\
1-5 & 24 & 8.7
\end{tabular}


$6-10$

$11-15$

$16-20$

$>20$

Table 2. Type of Health Care Setting

\begin{tabular}{lll}
\hline Health Care Setting & Frequency & Percentage \\
\hline Tertiary health care institution & 166 & 52.9 \\
Secondary health care institution & 82 & 26.1 \\
Primary health care centre & 40 & 12.7 \\
Private clinic & 19 & 6.0 \\
Maternity homes & 4 & 1.3 \\
Mean Age: Mean- $33.8 \pm 6.8$ & 3 & 1.0 \\
years. & & \\
Dispensaries & $\mathbf{3 1 4}$ & $\mathbf{1 0 0}$ \\
\hline Total &
\end{tabular}

Table 3. Knowledge of types of waste by respondents

\begin{tabular}{lll}
\hline Types of waste & Frequency & Percent \\
\hline General waste & 213 & 67.8 \\
Infectious waste & 151 & 48.1 \\
Highly infectious waste & 130 & 41.4 \\
Radioactive waste & 83 & 26.4 \\
Waste with high content of heavy & 58 & 18.5 \\
metal & & \\
Pharmaceutical waste & 107 & 34.1 \\
\hline
\end{tabular}

*multiple response

Table 4. Knowledge of method of health care waste disposal by respondents

\begin{tabular}{lll}
\hline Disposal & Frequency & Percent \\
Open dumping & 40 & 12.7 \\
\hline Incineration & 177 & 56.4 \\
\hline Open burning & 75 & 23.9 \\
\hline Through local council authority & 22 & 7.0 \\
\hline Total & & \\
\hline
\end{tabular}

Table 5. Respondent's awareness of existing policy on healthcare waste management and their knowledge of method of waste disposal

\begin{tabular}{llllll}
\hline Policy & \multicolumn{2}{l}{ Waste disposal by facility (\%) } & \multicolumn{2}{c}{ Total } \\
\cline { 2 - 5 } & Open dumping & Incineration & Open burning & Local authority & \\
Yes & $20(10.1)$ & $125(63.2)$ & $39(19.7)$ & $14(7.0)$ & $198(100)$ \\
No & $20(17.3)$ & $52(44.8)$ & $36(31.0)$ & $8(6.9)$ & $116(100)$ \\
\hline Total & $40(12.7)$ & $177(56.4)$ & $75(23.9)$ & $22(7.0)$ & $314(100.0)$ \\
\hline
\end{tabular}

$\mathrm{X}^{2}=11.214, \mathrm{df}=3, \mathrm{P}=0.011$ 
Texila International Journal of Public Health

Volume 5, Issue 3, Sep 2017

Table 6. Respondent knowledge on waste segregation and their practice of health care waste management

\begin{tabular}{lllll}
\hline \multicolumn{2}{l}{ Segregation of waste } & Practice $(\%)$ & & \multicolumn{2}{c}{ Total } \\
\cline { 2 - 5 } & Excellent & Fair & Poor & \\
\hline Yes & $74(24.8)$ & $170(57.0)$ & $54(18.2)$ & $298(100)$ \\
No & $0(0.0)$ & $7(43.8)$ & $9(56.2)$ & $16(100)$ \\
\hline Total & $74(23.6)$ & $177(56.4)$ & $63(20.1)$ & $314(100.0)$ \\
\hline
\end{tabular}

$\mathrm{X}^{2}=15.452, \mathrm{df}=2, \mathrm{P}=0.001$

Table 7. Respondents Attitude to health care waste management*

\begin{tabular}{|c|c|c|}
\hline Attitude & Frequency & Percent \\
\hline Health care waste management is respondent responsibility & 289 & 92.0 \\
\hline Health care waste management is a topical issue in Nigeria & 268 & 85.4 \\
\hline $\begin{array}{l}\text { Health care waste management is government responsibility } \\
\text { only }\end{array}$ & 97 & 30.9 \\
\hline $\begin{array}{l}\text { Health care waste management should be the responsibility } \\
\text { of only clinical staff }\end{array}$ & 116 & 36.9 \\
\hline $\begin{array}{l}\text { Health care waste management is an extra burden on the } \\
\text { clinical staff }\end{array}$ & 117 & 37.3 \\
\hline
\end{tabular}

Table 8. Awareness of policy on health care waste management and their practice of HCWM

\begin{tabular}{lllll}
\hline Policy & \multicolumn{2}{l}{ Practice (\%) } & Total \\
\cline { 2 - 4 } & Excellent & Fair & Poor & \\
\hline Yes & $57(28.8)$ & $109(55.0)$ & $32(16.2)$ & $198(100)$ \\
No & $17(14.7)$ & $68(58.6)$ & $31(26.7)$ & $116(100)$ \\
Total & $74(23.6)$ & $177(56.4)$ & $63(20.1)$ & $314(100.0)$ \\
\hline
\end{tabular}

$\mathrm{X}^{2}=10.432 \mathrm{df}=2 \mathrm{P}=0.005$ 


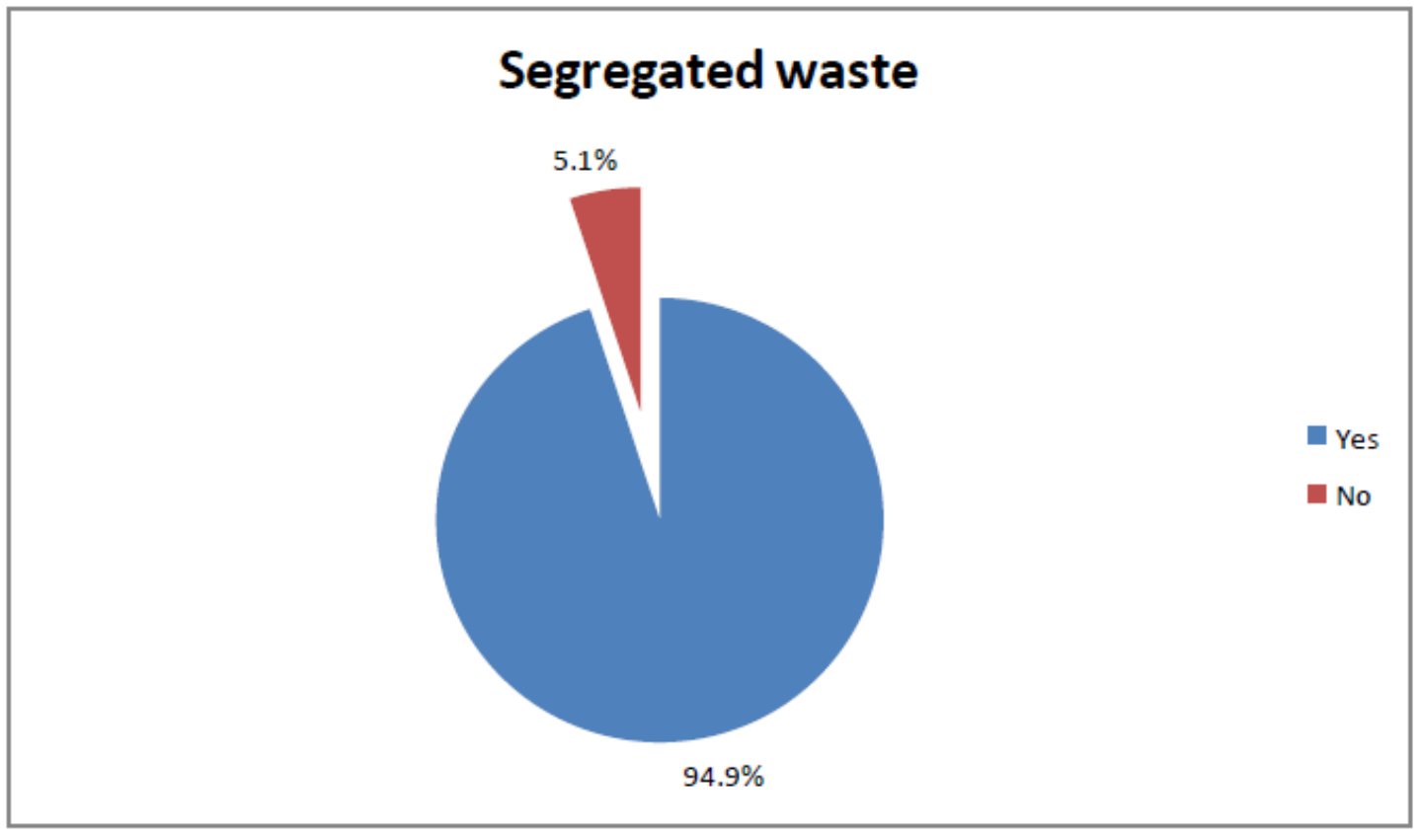

Figure 1. Respondent's knowledge of whether waste should be segregated Majority of the respondents 94.9\% knew that waste should be segregated whilst the remaining 5.1\% do not know.

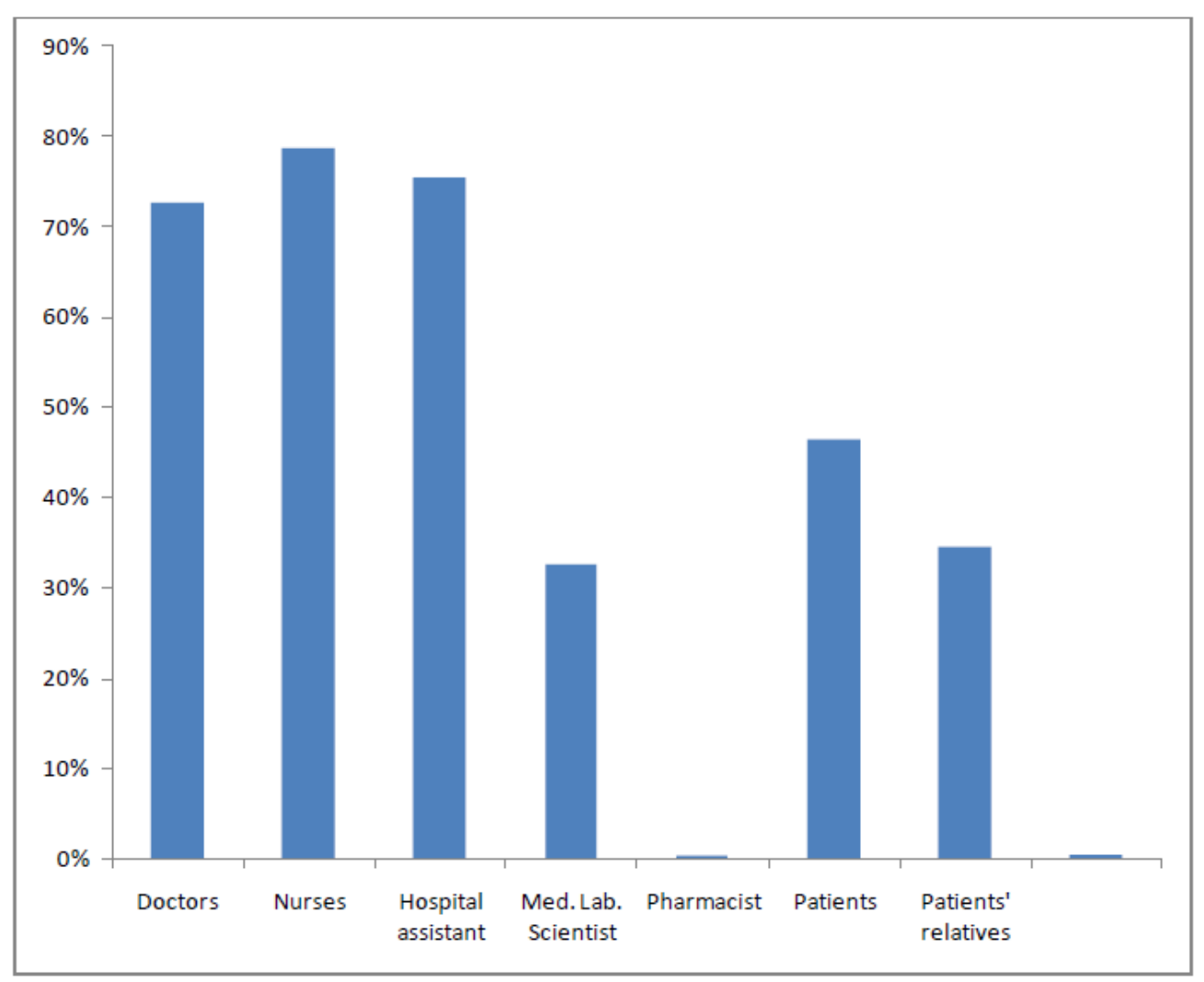

Figure 2. Knowledge of category health care staffs that are prone to infections from improper health care waste management 
A higher proportion of respondents $247(78.7 \%)$ believed nurses were at risk of contracting infections from improper health care waste management, followed by $228(72.6 \%)$ who believed doctors were at risk and only one respondent $1(0.3 \%)$ believed the pharmacist was at risk.

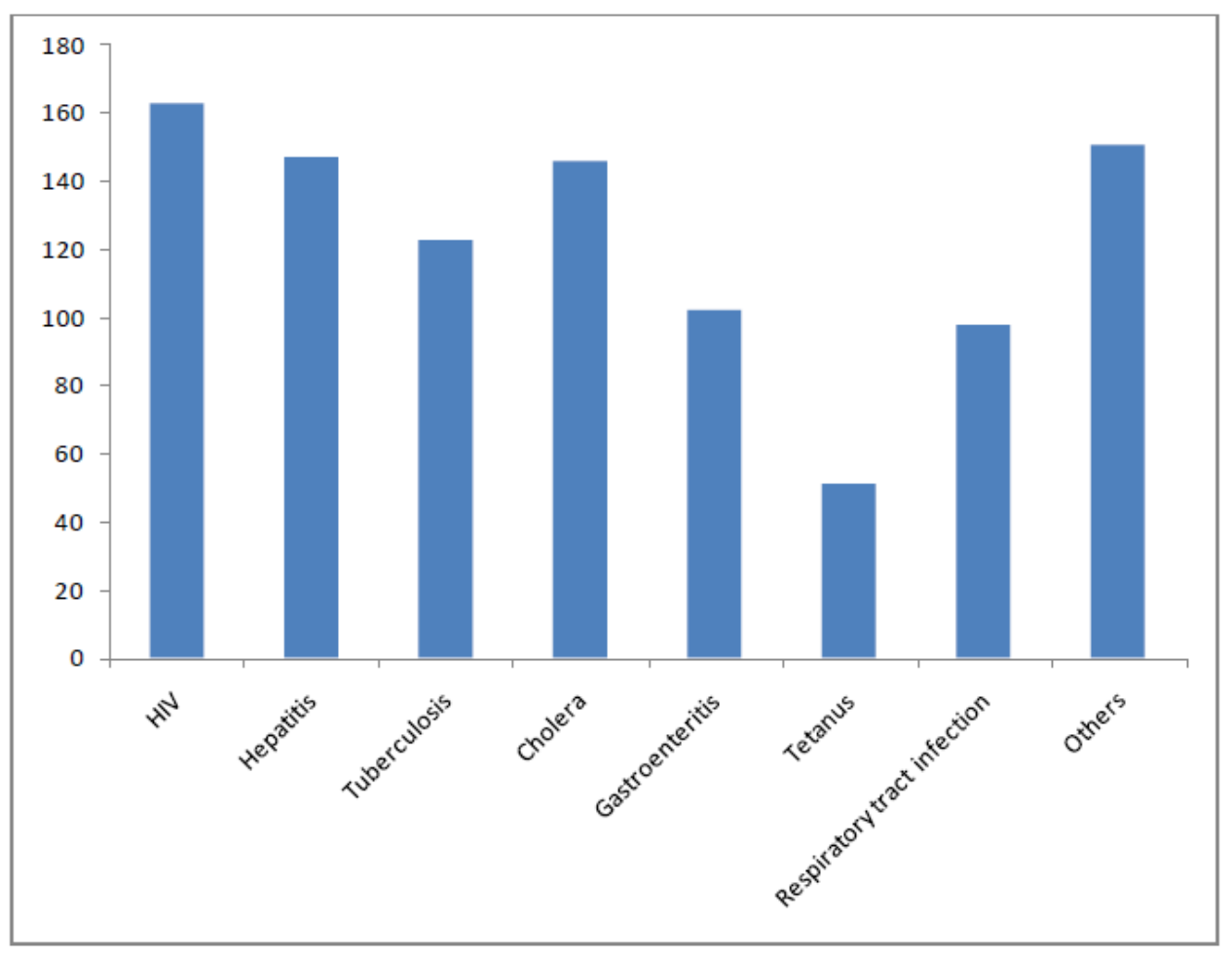

Figure 3. Knowledge of infections that can be gotten from improper waste management

A higher proportion of respondents 161 (51.9\%) knew H.I.V infections could be gotten from improper health care waste management, followed by 151 (48.1\%) who knew of other infections as common cold, malaria, dermatitis and only $51(16.2 \%)$ knew about tetanus gotten from improper health care waste management.

\section{Discussion}

The health care personnel population in Bida local government health facilities was predominantly below the middle age group with a mean age of $33.8 \pm 6.8$ years. About half of the respondents were within the age group of $31-40$ years. This could be consistent with the present campaign for increase awareness to education within the Bida area in the last two decades which has reflected in young graduates and secondary school leaver's influx into the civil service. It is not surprising that there was a higher number of females, especially with the current enlightenment on promoting female education. The finding that a higher number of respondents in this study were married may be linked to the fact that most of the respondents within the age bracket of $31-40$ are married in our society.

A higher number of respondents in this study are nurses and doctors. This is consistent with the fact that nurses are usually the majority in terms of population in most health care facilities. This is similar to a study carried out in a tertiary health care institution at Irrua in Edo State on Health Care Waste Management in Nigeria, which noted that Doctors and Nurses made up $90 \%$ of the study population. ${ }^{8}$

Over half of the respondents had worked for $1-5$ years, again showing a younger civil service in the health facilities. This could be due to recent establishment of a tertiary health care institution in Bida town which had to recruit new employees. 
Findings from this study showed an appreciable number of respondents had knowledge of general, infectious and highly infectious waste as types of waste. However, this knowledge is limited as only a few respondents had probably had any form of training on health waste management.

This study showed a high number of respondents who had knowledge that waste should be segregated, were also found to have had awareness of health care waste management. This finding is in contrast to a similar study in Jos on waste management in health care establishments within Jos metropolis. ${ }^{9}$ In the Jos study, it was found that waste were not segregated in any of the hospital, the health workers were not aware of any relevant hospital waste plan in place, and none of the staff had been trained on health care waste management.

Surprisingly knowledge of waste segregation were not affected by awareness of policy on health care waste management. The increase knowledge of waste segregation could be the result of billboards, posters on notice board within the hospital premises that had inform the respondents on health care waste management. A high number of the respondents from the study that had knowledge on waste segregation had good attitude and practice of health care waste management. There was a statistically significant association between knowledge of waste segregation and practice $(\mathrm{P}=001)$. These results are consistent with findings from a critical analysis of health care waste management in developed and developing countries with case studies from India and England. ${ }^{10}$ From this study in India and England, proper handling, segregation of health care wastes was done in these countries. The segregation of waste was done according to respective colour coded bags as prescribed by Biomedical waste management and handling rules. ${ }^{10}$ The report from an Abuja study on characterization and management of solid medical wastes showed that waste segregation was not practiced in hospitals within Abuja metropolis. ${ }^{11}$

A higher proportion of respondents from this study had knowledge of infections like HIV, Hepatitis etc. that could be gotten from improper health care waste disposal. This was consistent with same paper presentation above on overview of health care waste management in Nigeria, which noted that the health care workers faced the risk of infection due to blood borne pathogens and highlighted some important pathway of transmission of disease to health workers as percutaneous injection with contaminated sharps and also there could be contamination through faecal oral route e.g. Salmonellosis, hepatitis A. ${ }^{12}$

The study also showed that over half of the respondent had knowledge of incineration as a method of waste disposal. A higher number of respondents with knowledge of this method of waste disposal were aware of existing policy on health care waste management.

The attitude of respondents to health care waste management from this study is good. The study showed pharmacist and medical laboratory scientist had excellent and good attitude respectively. The older workers were also found to have had long years of working experience which had made the worker developed a better attitude as found in this study.

Health care waste management practice had been found to be good in this study as shown by majority of respondents that segregated wastes and used coloured coded bins in their various health facilities. The reason for this could be because workshops on health care waste management has been organized a few times in Bida Local Government, thus improving their awareness on health care waste management. This is contrary to the study in Jos on health care waste management in health establishment in the Jos metropolis which noted that the overall practice of health care waste management was poor. ${ }^{9}$

The practice of health care waste management was found from this study to be influenced by factors as a monitoring committee on standby, and an awareness of a policy on health care waste management. This results are contrary to those found in a study carried out in a tertiary health facility in Irrua in Edo state in Nigeria, where it was found that there were no health care waste management manual in place, no instructions or committee in place to oversee the health care waste management. ${ }^{8}$ This resulted to poor practice of health care waste management.

On working experience influencing health care waste management practice, the study showed, respondents with more years of working experience had a fair practice. This could be the result of having learnt these practice over years. 
Texila International Journal of Public Health

Volume 5, Issue 3, Sep 2017

\section{Conclusion}

The level of knowledge of health care waste management amongst health care workers in Bida local government area was fair. Their attitude as seen from results of this study was good.

The practice of health care waste management amongst health care staff was fair.

Awareness of existing policy, management, and having been certified from health care waste training, were found to affect the practice of health care waste management.

\section{Recommendation}

From the finding of the study, the following are been recommended.

1. There should be organization of workshops and seminars on health care waste management to improve their knowledge on health care waste management.

2. There should be posters, carrying information on health care waste management that will help to improve on their attitude.

3. There should be health talks, dramas which are informative on hazards that can be gotten from wrong practices of health care waste management. This will help to improve the practices of health care waste management.

4. The management of health facilities should make available personal protective devices/equipments to those workers involved in carrying and disposing of wastes as this will further encourage them.

5. Government should ensure that health care waste policies are widely circulated, to reach the common man, and each health facility has written plan on health care waste management and made available to all health care facility staffs.

\section{References}

[1]. Abah SO, Ohimain EI. Health Care Waste Management in Nigeria. Africa J. of Public Health and Epidemiology. 2011; 3(3): 99-110.

[2]. Bekir O. Health Care Waste Management in India, Discussion Paper. The World Bank Publication. 2003; 1-12.

[3]. Bassey E. South African Conference on Promoting Alternatives to Mercury in the Health Care Section. 2007; 3-5.

[4]. Bassey BE, Benka-Coker MO, Aliyu HAS. Characterization and Management of Solid Medical Waste in FCT Abuja Nigeria. African Health Sciences Journal. 2005; 6(2): 58 - 63.

[5]. Coker AD, Sangodoyin AY, Ogunlowo OO. Managing Hospital Wastes in Nigeria. Proceedings of the24 ${ }^{\text {th }}$ Water, Engineering and Development Centre (WEDC) Conference, Islamabad, Parkistan. 1999; 70 - 79002E.

[6]. Federal Government of Nigeria, Legal Notice on Publication of the details of the breakdown of the National and State Provisional Totals 2006 Census. Federal Republic of Nigeria Official Gazette 2007; 94 (24): B198.

[7]. Mukuolu OA. Overview of Health Care waste Management in Nigeria. Paper Presentation at Society for Quality Healthcare in Nigeria (SQHN) conference. 2009.

[8]. Ngwuluka N, Ochekpe N, Odumosu P, Sunday A. Waste Management in Health Care Establishment within Jos Metropolis, Nigeria. Africa Journal of Environmental Science and Technology.2009; 112 (3): 459 - 465.

[9]. Olatoye OB. Laboratory waste management in Nigeria. Basel convention workshop materials. 2005.

[10]. Phiss A, Giroult E, Rush Brook P. Safe management of waste from health care activities. World Health Organization WHO. Geneva. 1999.

[11]. Vijaya KG, Kavita D, Vidya B. A Critical Analysis of Health Care Waste Managemnet In developed and developing Counties, Case Studies From India and England. Proceedings on Sustainable Solid Waste Management. $2007 ; 134-141$.

[12]. World Health Organization. Do No Harm. Injection Safety in the Context of Infection Prevention and Control. Facilitators Guide. 2007; 79 - 97. 